\title{
PELATIHAN PENELITIAN TINDAKAN KELAS DAN PEMBUATAN ALAT PERAGA BAGI GURU-GURU SD SERTA PELATIHAN OSN BAGI SISWA SD DI TARUMAJAYA, KABUPATEN BEKASI PROVINSI JAWA BARAT
}

\author{
Ibnu Hadi $^{1}$, Aris Hadiyan Wijaksana ${ }^{2}$, Dwi Antari Wijayanti ${ }^{3}$, Ratna Widyati ${ }^{4}$ \\ Fakultas Matematika dan IPA, Universitas Negeri Jakarta \\ 1ibnu_hadi@unj.ac.id 22arishadiyan@gmail.com²dwi_antari@unj.ac.id \\ ${ }^{4}$ ratna.widyati@gmail.com
}

\begin{abstract}
This Community Service Program (PkM) aims to improve the soft-skill ability of elementary school teachers and students in Tarumajaya, Bekasi, West Java, Indonesia. The activities carried out in the form of Classroom Action Research training and Creating Teaching Aids for teachers and training on the National Science Olympiad for their students. The method employed in the PkM was through material exposure (lectures), discussion, question and answer and direct practice of the material provided. The activity of the teacher begins with the exposure of the Classroom Action Research Material to the teacher delivered by the guest speaker. At the beginning, the teacher was asked to submit learning problems in the classroom. Based on the problem presented, then the resource person provided the material and adjusted it to solve the problem. The goal is that the teachers can solve the problems raised using appropriate and interesting learning methods and teaching aids. Furthermore, the teachers were directed to focus on one problem which is then revealed in the form of problem-solving steps. As for the material for making teaching aids, teachers were provided with materials to create the teaching aids and they were given a guide to make the aids as needed. Beginning with the presentation of material about the concept of teaching aids, participants were guided to make teaching aids based on the mathematical concepts to be appointed. While in the student section, the participants conducted the National Science Olympics training activities by taking the pre-test, followed by material exposure and discussion of questions and post-tests. Because students are not familiar in answering the questions about the type of National Science Olympiad, they were guided to complete each question and taught the resolution strategies. The results of this community service has been uploaded to https://youtu.be/cmoITKDbMOo
\end{abstract}

Keywords: Classroom Action Research, Teaching Aids, National Science Olympiad.

\begin{abstract}
Abstrak
Pengabdian Kepada Masyarakat (PkM) ini bertujuan untuk meningkatkan kemampuan soft-skill guruguru dan siswa Sekolah Dasar (SD) di Tarumajaya, Kabupaten Bekasi Provinsi Jawa Barat. Kegiatan yang dilakukan dalam bentuk pelatihan Penelitian Tindakan Kelas dan Pembuatan Alat Peraga bagi guru-guru serta pelatihan tentang Olimpiade Sains Nasional bagi siswa-siswanya. Metode pada PkM ini melalui paparan materi (ceramah), diskusi, tanya jawab dan praktek langsung terhadap materi yang diberikan. Kegiatan pada guru di awali dengan paparan materi Materi Penelitian Tindakan Kelas terhadap guru yang disampaikan oleh narasumber. Pada bagian awal, guru diminta menyampaikan permasalahan pembelajaran yang ada di dalam kelas. Berdasarkan masalah yang disampaikan, kemudian narasumber memberikan materi dan disesuaikan dengan permasalahan. Tujuannya agar para guru dapat menyelesaikan permasalahan yang diajukan menggunakan metode pembelajaran yang sesuai dan menarik serta alat peraga. Selanjutnya guru diarahkan untuk fokus pada satu masalah yang kemudian diturunkan dalam bentuk langkah-langkah penyelesaian masalah. Sedangkan pada materi Pembuatan Alat Peraga, guru-guru dibekali dengan bahan untuk membuat alat peraga dan dituntun untuk membuat alat peraga sesuai kebutuhan. Di awali dengan paparan materi tentang konsep alat peraga, peserta dituntun membuat alat peraga berdasarkan konsep matematika yang akan diangkat. Sedangkan pada bagian siswa, para peserta melakukan kegiatan pelatihan Olimpiade Sains Nasional dengan mengikuti pre test, dilanjutkan paparan materi dan pembahasan soal serta post test. Karena para siswa belum terbiasa dalam menjawab soal tipe Olimpiade Sains Nasional, mereka dituntun
\end{abstract}


dengan bertahap dalam menyelesaikan setiap soal serta disampaikan bagaimana strategi penyelesaiannya. Hasil pengabdian kepada masyarakat ini juga diunggah ke https://youtu.be/cmoITKDbMOo.

Kata Kunci: Penelitian Tindakan Kelas, Alat Peraga, Olimpiade Sains Nasional

\section{PENDAHULUAN}

Selama ini matematika menjadi materi yang diajarkan di dalam kelas dan disampaikan sebagai kewajiban kurikulum baik di tingkat sekolah dasar, menengah maupun perguruan tinggi. Konsep yang dibangun dalam matematika merupakan konsep yang abstrak sehingga menjadikan matematika "terkesan" sebagai "sesuatu" yang tidak menyenangkan. Di sisi lain, pemerintah mencanangkan pendidikan sebagai konsep yang menyeluruh dan terintegrasi baik dari materi pelajaran yang bersifat teori maupun materi non-teori (praktek). Dalam hal ini, matematika sebagai salah satu materi yang diajarkan di sekolah harus disampaikan dalam bentuk teori yang menyeluruh dan terintegrasi dalam kehidupan sehari-hari. Lebih lanjut, kurikulum 2013 yang dicanangkan pemerintah menekankan aspek keterampilan sebagai salah satu hal yang harus dicapai di dalam sistem pembelajaran. Akibatnya, pembelajaran matematika pun dituntut untuk memenuhi aspek-aspek yang tertuang di dalam kurikulum 2013.

Namun dalam perkembangannya, kurikulum 2013 bukan menjadi kurikulum yang dipegang dan diwajibkan untuk diterapkan di sekolah. Revisi dan kritisi terhadap kurikulum ini terus berkembang sehingga pematangan terhadap kurikulum ini masih berlanjut. Akan tetapi, aspek penting yang ada di dalam kurikulum 2013 maupun kurikulum sebelumnya pada hakikatnya tidak boleh hilang. Kemampunan guru dan siswa dalam aspek pengetahuan dan ketrampilan mutlak ditumbuhkan dan dikembangkan sehingga kompetensi pendidik dan peserta didik menjadi lebih baik. Tantangan masyarakat ke depaannya mengharuska guru dan siswa harus memiliki kemampuan yang terintegrasi dari sisi soft skill dan hard skill. Oleh karena itu, diperlukan suatu proses dan metode yang baik untuk meningkatkan kemampuan guru dan siswa.

Bagi guru, kemampuan meneliti dan membuat suatu tulisan menjadi keharusan untuk mengembangkan kompetensi mereka sebagai pendidik dan tenaga profesional. Untuk itu, pengetahuan tentang bagaimana membuat suatu penelitian dan pengolahan data menjadi sesuatu yang penting bagi guru. Wilayah kajian yang dijadikan penelitian untuk guru sangat luas macamnya sehingga guru dapat memilih dengan leluasa hal menarik apa yang dapat dilakukan menjadi penelitiannya. Sebagai contoh, penelitian tindakan kelas menjadi pilihan yang dapat dilakoni guru untuk lebih meningkatkan kualitas pembelajaran di kelas. Untuk menunjang penelitian tersebut, guru wajib memiliki pengetahuan tentang konsep penelitian kualitatif ataupun kuantitatif disamping kemampuan dalam mengolah data penelitian. Lebih lanjut, ketika pengajaran di kelas membutuhkan media sebagai sarana penunjang pembelajaran, 
guru harus memiliki kemampuan untuk meciptakan suatu alat peraga untuk memberikan penguatan untuk menjelaskan suatu konsep. Konsekuensinya, guru harus dituntut harus menguasai bagaimana menciptakan alat peraga yang baik untuk pembelajaran. Kemampuan lain dari guru yang bisa dikembangkan terkait media yaitu kemampuan menggunakan perangkat lunak yang mendukung pembelajaran. Konsep matematika sebagai materi yang banyak di sampaikan di kelas dapat disajikan menggunakan aplikasi komputer seperti Geogebra. Ketika guru menguasai perangkat lunak ini, diharapkan siswa dapat lebih menangkap konsep yang disampaikan guru sehingga mereka lebih matang dalam menerima dan memahami suatu materi. Oleh karena itu, kemampuan guru dalam pengetahuan membuat penelitian dan media menjadi sangat penting.

Di lain sisi, kebutuhan siswa tidak sekedar mendapatkan materi dan konsep dari guru. Mereka juga perlu dilatih lebih lanjut dalam mematangkan pengetahuan yang sudah didapat di kelas. Standar pengetahuan yang didapat di sekolah hendaknya diujikan dalam suatu proses yang dapat menguji sejauh mana kemampuan yang sudah mereka capai. Ajang perlombaan seperti olimpiade menjadi penting agar mereka termotivasi menjadi lebih baik. Pihak sekolah belum mampu mewadahi minat siswa yang memiliki kemampuan lebih untuk dilatih dan dilombakan dalam ajang seperti olimpiade maupun kompetisi antar sekolah baik tingkat nasional maupun internasional. Padahal, jika siswa sering dilatih dan diikutkan dalam ajang seperti itu, kepercayaan diri mereka dapat tumbuh dan berkembang dengan baik. Begitu juga dari sisi kemampuan teknologi informasi, siswa harus disiapkan sedemikian rupa untuk menghadapi kompetisi global yang sebentar lagi akan dijalani mereka. Konsep Masyarakat Ekonomi Asean (MEA) tahun 2015 akan menjadi tantangan tersendiri bagi siswa yang nantinya akan masuk ke dalamnya. Artinya, persiapan kemampuan teknologi informasi menjadi penting untuk siswa sekarang ini. Jadi, kemampuan teknologi dan menumbuhkan kepercayaan diri siswa melalui ajang kompetisi mutlak diperlukan untuk menyiapkan mereka di masa depan.

Dari uraian di atas, maka dapat disimpulkan bahwa bagi guru, pelatihan mengenai penelitian kualitatif dan kuantititatif, penelitian tindakan kelas, pelatihan pembuatan alat peraga, dan pelatihan olimpiade bagi siswa menjadi hal penting yang harus dilakukan untuk memberikan bekal sebagai upaya meningkatkan kompetensi mereka. Artinya, perlu ada usaha bagaimana hal ini bisa tercapai dan maksimal dalam pelaksanaannya.

\section{METODE PELAKSANAAN}

Metode yang digunakan pada program kegiatan pengabdian kepada masyarakat ini adalah pembekalan teori dan praktek. Teori diberikan dalam bentuk pelatihan oleh narasumber, sedangkan praktek dilakukan secara berkelompok dengan didampingi dosen sebagai narasumber. 
Pelatihan menggunakan metode ceramah dan demonstrasi (praktek) dengan uraian kegiatan sebagai berikut:

1. Pada awal kegiatan, para peserta akan diberikan teori-teori pendukung yang berkaitan dengan aspek-aspek yang akan dilatihkan.

2. Peserta berlatih atau melakukan praktek secara mandiri atau berkelompok untuk berlatih sesuai materi yang diberikan.

Untuk melaksanakan kegiatan tersebut digunakan beberapa metode pelatihan, yaitu:

1. Metode Ceramah. Metode ceramah dipilih untuk memberikan penjelasan konsep atau materi di pelatihan.

2. Metode Tanya Jawab. Metode tanya jawab sangat penting bagi para peserta pelatihan, baik di saat menerima penjelasan teoritis maupun pada pelaksaan praktek berupa latihan soal atau kasus.
3. Metode Simulasi. Metode simulasi ini sangat penting diberikan kepada para peserta pelatihan untuk memberikan kesempatan mempraktekan materi pelatihan yang diperoleh.

Harapannya, peserta pelatihan akan benar-benar menguasai materi pelatihan yang diterima, mengetahui tingkat kemampuannya dan kompetensinya.

\section{HASIL DAN PEMBAHASAN}

Di bagian guru, materi di awali paparan oleh narasumber Drs. Tri Murdiyanto, M.Si dan tim UNJ yaitu Dwi Antari Wijayanti, M.Pd. Mereka memaparkan materi PTK. Narasumber dan tim memberikan pengantar mengenai konsep PTK dan hal-hal yang terkait dengan penyusunan PTK. Dalam paparan materi ini, peserta diberikan materi langkah-langkah dalam menyusun PTK mulai dari menemukan masalah, menyusun ke dalam suatu material PTK sampai pembuatan karya ilmiah yang memuat masalah di dalam PTK tersebut.

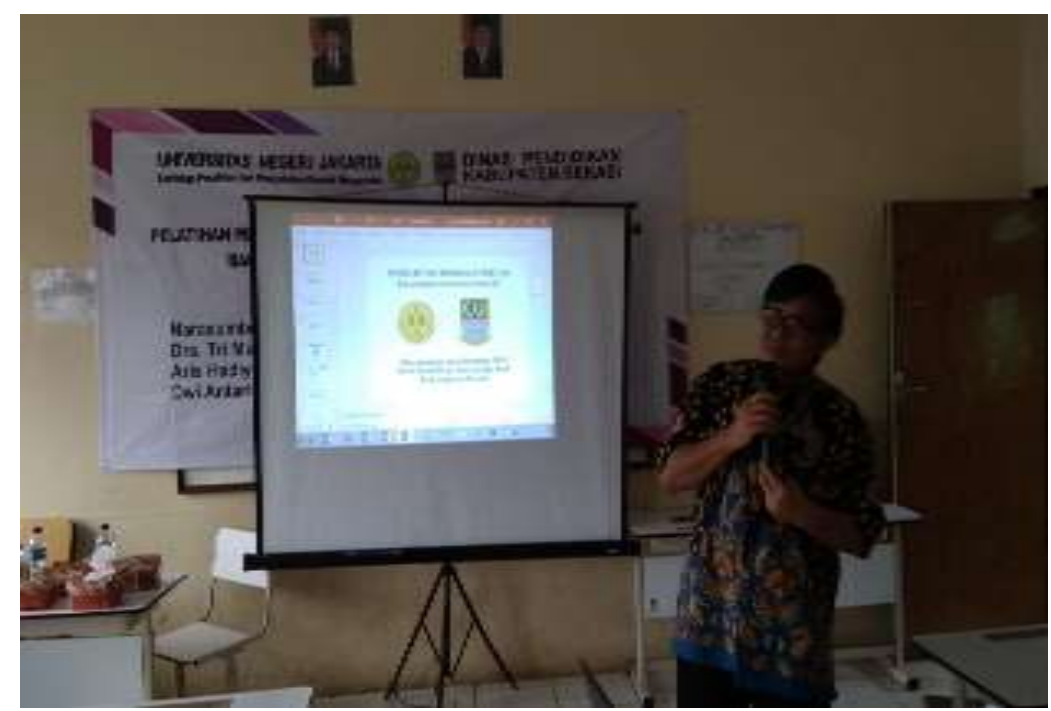

Gambar 1. Narasumber memberikan materi

Materi yang dipaparkan oleh meminta para peserta untuk narasumber dimulai dengan cara mengidentifikasi masalah-masalah 
pembelajaran yang sering ditemui di kelas masing-masing. Masalah-masalah yang ditemui peserta selama mereka mengajar di kelas sangat beragam, antara lain:

1. Siswa masih belum memahami materi yang digunakan disampaikan oleh guru

2. Siswa merasa bosan saat guru menyampaikan materi di depan kelas

3. Siswa membaca buku yang tidak berhubungan dengan materi yang disampaikan oleh guru, misalnya komik

4. Siswa tidak hafal operasi perkalian

5. Siswa membuat gambar atau coretcoretan di meja ataupun kertas mencatat saat guru menyampaikan materi

6. Siswa tidak mempu bekerja sama saat mereka belajar dlama kelompok

7. Siswa belum memiliki kemampuan berpikir secara sistematis saat menyelesaikan permasalahan dalam matematika

8. Siswa melamun saat kegiatan belajar mengajar.

Berdasarkan berbagai macam masalah yang dihadapi oleh para peserta pelatihan tersebut, narasumber kemudian memberikan penjelasan materi bagaimana cara mengatasi permasalahan di kelas. Permasalahan tersebut bisa diatasi dengan cara guru menggunakan metode pembelajaran yang menarik ataupun menggunakan alat peraga. Langkah selanjutnya, narasumber meminta peserta untuk mengatasi masalah yang dihadapi peserta di kelas difokuskan menjadi satu jenis permasalahan yang akan dipecahkan.
Setelah peserta memilih satu masalah yang akan diselesaikan, kemudian narasumber membimbing peserta untuk menentukan langkah dalam menyelesaikan masalah tersebut. Para peserta memutuskan untuk memilih langkah-langkah penyelesaian masalah, antara lain:

1. Guru mengggunakan alat peraga yang menarik dan mudah dioperasikan.

2. Guru menggunakan media pembelajaran berupa video.

3. Guru mengajak siswa untuk menggunakan lingkungan sekolah dalam mengajarkan materi matematika

4. Guru menggunakan metode/model pembelajaran yang menarik dan kontemporer, antara lain: Pembelajaran Kooperatif (tipe NHT/STAD/Jigsaw/TAI/Make a Match/TSTS), Pembelajaran Berbasis Masalah (PBL), Cotextual teaching and Learning (CTL), Pendidikan Matematika Realistik Indonesia (PMRI), Quanu Teaching.

5. Guru meminta siswa untukl menghapal perkalian

6. Guru meminta siswa agar selalu membaca materi selanjutnya di rumah

7. Guru meminta siswa untuk selalu fokus saat guru menjelaskan materi di depan kelas.

Langkah selanjutnya narasumber membimbing peserta untuk menentukan judul PTK. Judul PTK paling tidak memuat empat unsur yang dituangkan dalam pertanyaan berikut:

1. Apa yang akan diperbaiki dalam pembelajaran di kelas? 
2. Bagaimana cara memperbaiki masalah tersebut?

3. Mata Pelajaran/materi/tema/sub tema mana yang akan diperbaiki?

4. Dimanakah perbaikan pembelajaran tersebut dilakukan?

Dari empat unsur tersebut dapat dibuat sebuah judul, misalnya:

"Upaya meningkatkan hasil belajar

Matematika melalui Pembelajaran Kooperatif tipe STAD untuk siswa kelas

IV SDN Setia Bhakti Jakarta"

"Upaya meningkatkan motivasi belajar Matematika untuk operasi Perkalian melalui PMRI untuk siswa kelas III SDN Karya Bhakti Jakarta"

"Upaya meningkatkan Kemampuan Membaca Cerita melalui Metode Bermain Peran untuk siswa kelas I SDN Sidomukti Jakarta"

Setelah memberikan contohcontoh judul tersebut, narasumber kemudian membimbing peserta untuk membuat judul-judul sesuai masalamasalah yang telah diidentifikasi dan pemecahan-pemecahan masalah yang telah direncanakan oleh masing-masing peserta.

Materi pelatihan terakhir adalah merumuskan suatu permasalahan yang akan menjadi fokus dalam Penelitian Tindakan Kelas. Perumusan masalah ini dapat diturunkan dari judul yang telah dibuat oleh masing-masing peserta. Sebagai contoh perumusan masalah yang diturunkan dari contoh judul di atas adalah:
1. Bagaimana upaya meningkatkan hasil belajar Matematika melalui Pembelajaran Kooperatif tipe STAD untuk siswa kelas IV SDN Setia Bhakti Jakarta?

2. Bagaimana upaya meningkatkan motivasi belajar Matematika untuk operasi Perkalian melalui PMRI untuk siswa kelas III SDN Karya Bhakti Jakarta?

3. Bagaimana upaya meningkatkan Kemampuan Membaca Cerita melalui Metode Bermain Peran untuk siswa kelas I SDN Sidomukti Jakarta?

Setelah melakukan pelatihan PTK untuk guru-guru SD Tarumajaya Bekasi didapatkan kesimpulan sebagai berikut:

1. Peserta sangat antusias dalam mengikuti pelatihan, terutama guru-guru yang akan mengajukan kenaikan pangkat.

2. Permasalahan-permasalahan yang dihadapi peserta di kelas tempat mengajar masing-masing ternyata sangat beragam.

3. Tidak semua peserta memiliki kemampuan menulis ilmiah, sehingga banyak sekali yang kesulitan dalam menulis sebuah laporan PTK.

4. Sebagian peserta masih kesulitan dalam mengidentifikasi masalah karena masalah-masalah tersebut sudah biasa terjadi di kelas dan sudah dianggap bukan suatu masalah dalam pembelajaran lagi.

Ada beberapa peserta yang masih belum bisa mengoperasikan komputer sehingga kesulitan dalam membuat laporan PTK. 
Paparan materi PTK ini dilakukan sekitar 2 jam dan disertai diskusi dan tanya jawab antara peserta dengan pemateri. Para peserta antusias dalam mengikuti materi, khususnya ketika mendefinisikan masalah yang akan dijadikan PTK oleh para guru. Sebelumnya mendapatkan materi, para guru diminta mengisi kuesioner untuk mengetahui kondisi awal sebelumnya. Pada umumnya, para guru sudah sering mendapatkan materi pelatihan sesuai dengan profesinya sebagai guru, akan tetapi khsusus untuk pelatiha PTK ini mereka banyak yang mengharapkan untuk mendapatkan pelatihan materi PTK. Terkait dengan administrasi mereka dalam kenaikan pangkat dan arahan dari pengawas, tentunya PTK menjadi sesuatu yang sangat penting untuk para guru untuk meningkatkan kompetensinya.

Materi selanjutnya yang didapatkan oleh para guru adalah materi alat peraga. Pada bagian ini, para guru diajak untuk terlibat dalam pembuatan alat peraga khususnya materi matematika. Materi diisi dan dipaparkan oleh Aris Hadiyan Wijaksana, M.Pd sebagai narasumber dan tim dari UNJ. Beliau memberikan kesempatan kepada para guru untuk memahami pentingnya suatu alat peraga di dalam pembelajaran matematika. Di awali dengan paparan tentang bagaimana membuat alat peraga dan konsep-konsep yang menyertainya, dilanjutkan dengan praktek langsung dalam pembuata alat peraga. Para guru sangat antusias karena mereka bisa mengalami langsung proses pembuatannya dan memahami makna dari suatu alat peraga.

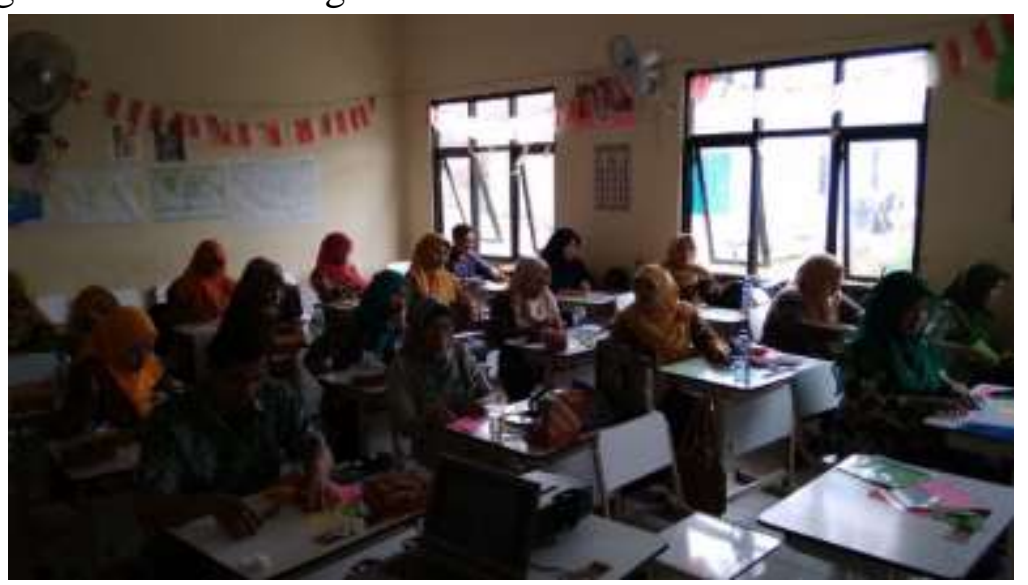

Gambar 2. Peserta dengan alat peraga

Tampak pada gambar, para peserta mengalami proses pembuatan alat peraga dan mencoba konsep matematika apa yang bisa diterapkan pada alat peraga tersebut. Di sini diperlukan imajinasi dan eksplorasi dari para guru untuk bisa menerjemahkan alat peraga yang dibuat. Artinya para guru diminta mencoba semua kemungkinan yang bisa timbul dari suatu alat peraga yang dibuat. Diharapkan, saat para guru menjelaskan kepada siswa, mereka sudah siap dengan materi dan pembelajarannya menggunakan alat peraga. Ternyata beberapa guru juga memiliki perpektif yang berbeda di dalam melihat alat peraga 
ini, sehingga konsep matematika yang dimunculkan juga bisa beragam. Prinsipnya, suatu alat peraga dapat dipakai dalam pembelajaran matematika ketika pembuatan alat peraga dilakukan langsung oleh guru, sehingga guru tersebut dapat mengetahui dasar konsep yang berlaku pada alat peraga tersebut. Alat peraga yang digunakan dibuat semudah mungkin dari sisi perolehan bahan, dan dapat dipahami oleh peserta didik.

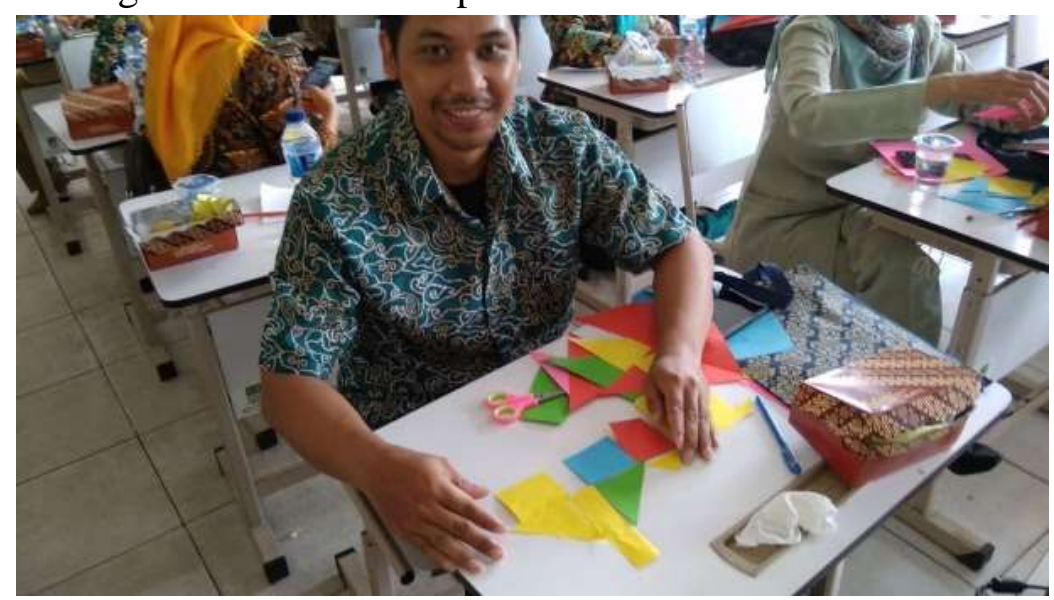

Gambar 3. Guru sedang membuat alat peraga

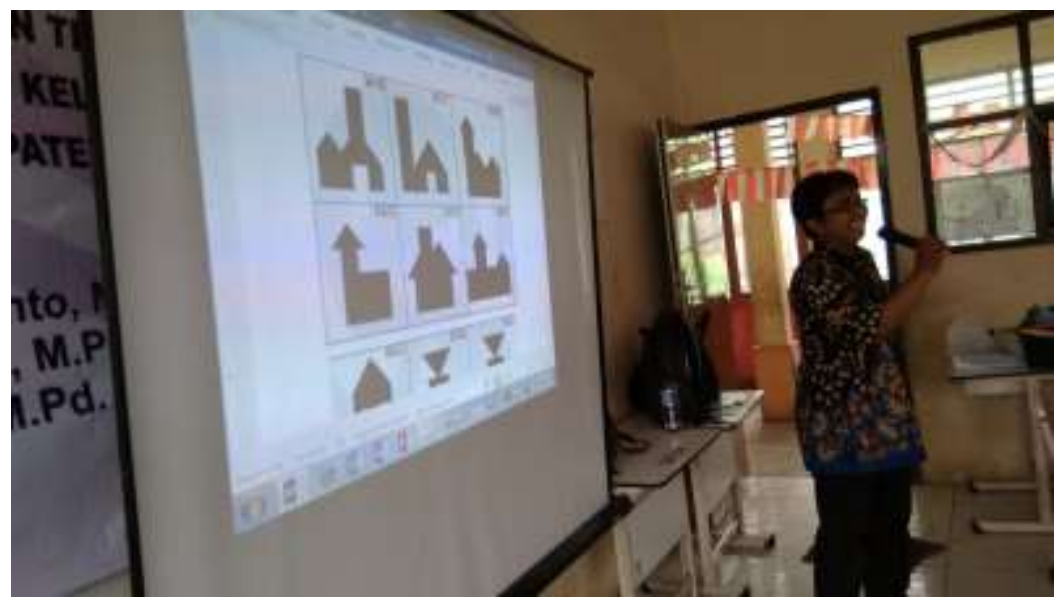

Gambar 4. Paparan materi alat peraga

Sebagai catatan, hasil dari pelaksanaan materi alat peraga ini dapat dibawa pulang oleh guru langsung untuk dipelajari lebih dalam. Sesuai paparan materi alat peraga oleh narasumber, beragam bentuk dari potongan kertas dapat dikombinasikan menjadi berbagai bentuk yang menarik. Untuk pembelajaran matematika khususnya pengenalan bentuk, alat peraga ini cukup mudah untuk dilakukan oleh guru maupun siswa. Materi yang diberikan sekitar 2 jam ini memberikan wawasan mendasar kepada guru tentang bagaimana pentingnya alat peraga dalam suatu proses pembelajaran khususnya materi matematika.

Pada gambar di bawah berikut, 
tampak narasumber memberikan arahan langsung kepada peserta ketika mencoba alat peraga. Antusias peserta dalam membuat alat peraga yang langsung dibimbing narasumber terlihat dengan banyaknya pertanyaan yang diajukan selama pemberian materi. Keseriusan para guru dalam membuat alat peraga tetap terlihat dalam rangka membuat alat peraga dan menerjemahkan substansi dari alat peraga yang dibuat

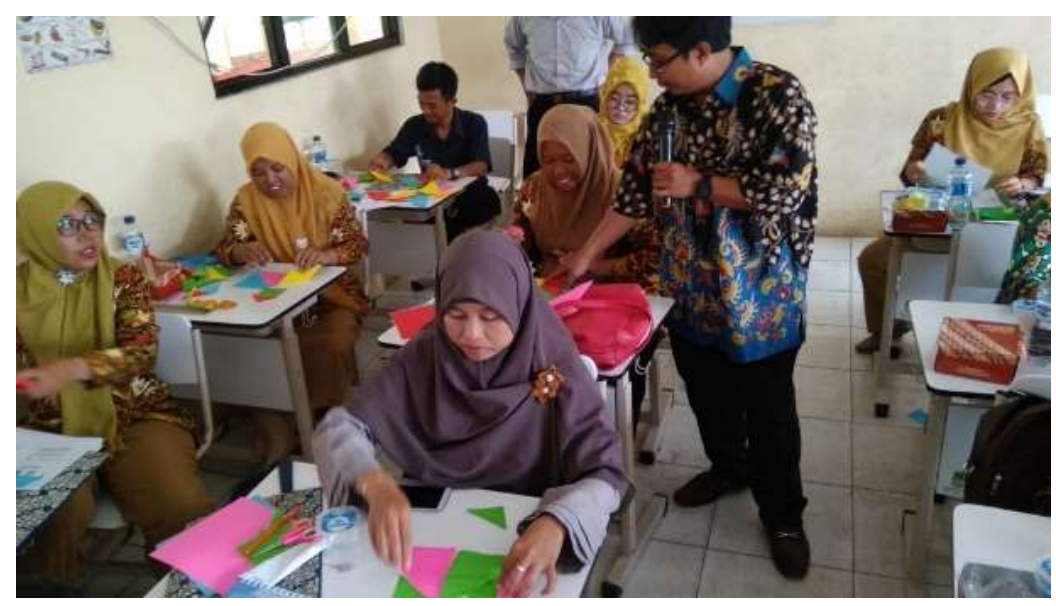

Gambar 5. Interaksi Peserta dan Narasumber

Di lain pihak, pelaksanaan PkM bagi siswa untuk pelatihan soal-soal olimpiade nasional juga terlaksana dengan baik. Pada pelatihan siswa, dimulai dengan tes awal untuk mengetahui kemampuan mereka dalam mengenali dan menjawab soal. Setelah mengerjakan tes awal, para siswa dibimbing untuk mengerjakan soal-soal yang sudah disiapkan melalui paparan narasumber. Setelahnya siswa diberikan tes akhir untuk melihat pengaruh dari pembelajaran yang dilakukan pada saat kegiatan PkM. Di akhir acara, diberikan soal simulasi lomba kepada para siswa sebagai pemacu semangat untuk mengukur seberapa jauh pemahaman siswa terhadap soal-soal OSN.
Didapatkan tiga pemenang dengan cara menghitung nilai akumulasi dari tes awal, tes akhir dan soal lomba. Secara umum, para siswa antusias dalam menyelesakan soal-soal olimpiade. Akan tetapi, masih banyak siswa yang bingung karena banyak yang baru melihat soal olimpiade. Dalam paparan materi, beberapa kali narasumber harus mengulang dan mengingatkan kepada siswa tentang konsep yang pernah dipelajari di sekolah.

Pada prinsipnya, materi pada soalsoal OSN menggunakan nalar dan logika siswa sehingga perlu berlatih lebih lanjut. Pembelajaran OSN merupakan pembelajara berkelanjutan sehingga tidak bisa langsung dirasakan hasilnya 


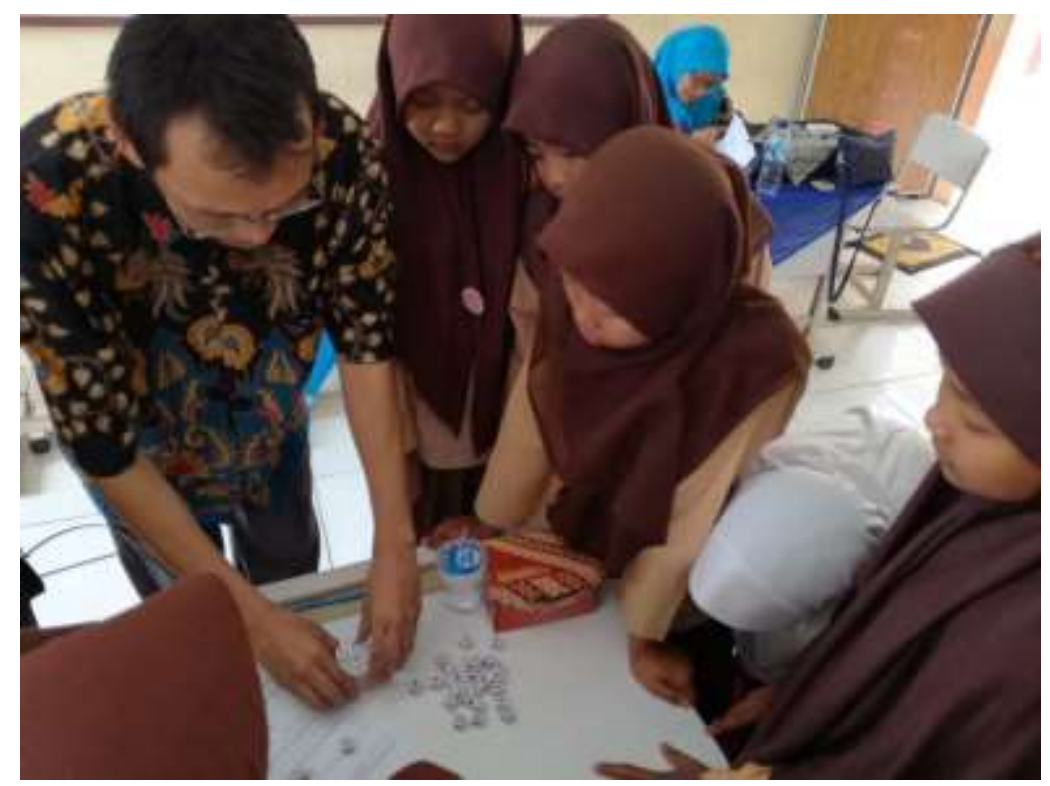

Gambar 6. Kegiatan Eksplorasi Alat Peraga

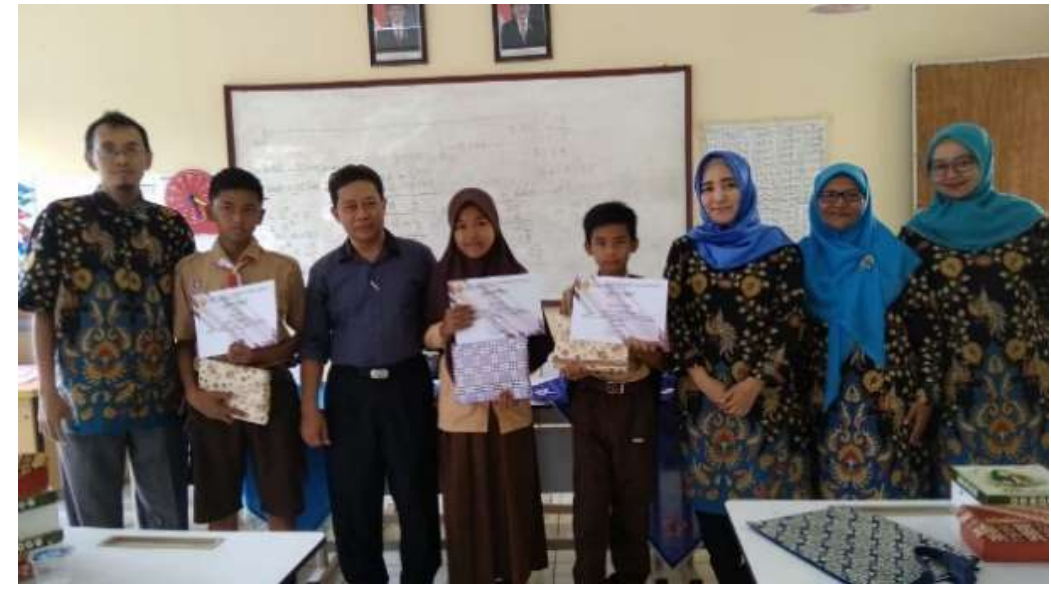

Gambar 7. Aktifitas pelatihan Olimpiade Sain Nasional

Secara kuantitatif, setelah dilakukan pelatihan OSN terhadap siswa, didapat persentase kenaikan nilai pre-test ke post-test adalah $93 \%$, persentase nilai pre-test ke post-test yang sama adalah $7 \%$, dan persentase penurunan nilai pretest ke post-test adalah $0 \%$. Sedangkan persentase kenaikan nilai post-test ke lomba adalah $13 \%$, persentase nilai tetap dari post-test ke soal lomba adalah $67 \%$, dan persentase nilai menurun dari posttest ke soal lomba adalah $20 \%$. Hasil ini menggambarkan tingkat kemampuan siswa siswa yang ikut dalam pelatihan soal OSN pada PkM masih jauh dari yang diharpkan. Hal ini terjadi disebabkan karena mereka dalam keseharian di sekolahnya belum mendapatkan bimbingan dan pelatihan khusus terkait materi dan soal-soal olimpiade. Berdasarkan hasil ini, maka perlu ada tindaklanjut dalam kegiatan PkM berikutnya untuk lebih meningkatkan kemampuan siswa khususnya dalam menyelesaikan soal-soal olimpiade Nasional. 
Tabel 1. Hasil Perolehan Nilai Siswa Pada Pelatihan Olimpiade Sains Nasional

\begin{tabular}{rlccccc} 
No & \multicolumn{1}{c}{ Nama } & Sekolah & Pretest & Posttest & $\begin{array}{c}\text { Soal } \\
\text { Lomba }\end{array}$ & Rata-Rata \\
\hline $\mathbf{1}$ & Muhammad Ralhan Rabbani & SDN Pusaka Rakyat 01 & 1 & 2 & 6 & 3,00 \\
\hline $\mathbf{2}$ & Moh. As'ad Alwi & SDN Pusaka Rakyat 01 & 2 & 3 & 3 & 2.67 \\
\hline $\mathbf{3}$ & Selvi Aulla & SDN Pahlawan Setia 01 & 1 & 2 & 4 & 2,33 \\
\hline $\mathbf{4}$ & Zain Zaidan & SDN Pahlawan Setia 01 & 2 & 3,5 & 1 & 2,17 \\
\hline $\mathbf{5}$ & Sherly Widya Putri & SDN Pusaka Rakyat 01 & 1 & 2 & 2 & 1,67 \\
\hline $\mathbf{6}$ & Mutla Hafiz & SDN Pusaka Rakyat 01 & 0 & 2 & 2 & 1,33 \\
\hline $\mathbf{7}$ & Aulia Putri Ashara & SDN Setia Mulya 01 & 0 & 2 & 2 & 1,33 \\
\hline $\mathbf{8}$ & Tiara Ayu Amelia & SDN Setia Mulya 01 & 0 & 2 & 1,5 & 1,17 \\
\hline $\mathbf{9}$ & M. Rafa Ronaldo & SDIT Citra Bansa & 1 & 2 & 0 & 1,00 \\
\hline $\mathbf{1 0}$ & Zahra Aulia & SDN Pusaka Rakyat 01 & 0 & 1 & 1 & 0,67 \\
\hline $\mathbf{1 1}$ & Rahadatul Afiyah & SDN Pusaka Rakyat 01 & 0 & 1 & 1 & 0,67 \\
\hline $\mathbf{1 2}$ & Qoies Disa Lita Palupi & SDN Pusaka Rakyat 01 & 0 & 1 & 1 & 0,67 \\
\hline $\mathbf{1 3}$ & Khonita Salsabila & SDN Pusaka Rakyat 01 & 0 & 1 & 1 & 0,67 \\
\hline $\mathbf{1 4}$ & Agnya Atatita Rahma & SDIT Citra Bansa & 0 & 1 & 1 & 0,67 \\
\hline $\mathbf{1 5}$ & Anggita Pertiwi Caesarani & SDN Pusaka Rakyat 01 & 0 & 0 & 0 & 0.00 \\
\hline
\end{tabular}

\section{PENUTUP}

Pelaksanaan PkM di Tarumajaya, Kabupaten Bekasi pada hari Sabtu, 27 Oktober 2018 dapat terlaksana dengan baik. Sasaran guru berupa pelatihan PTK dan Alat Peraga tercapai sesuai indikator yang diharapkan. Sedangkan untuk pemberian materi kepada siswa berupa materi OSN masih memiliki catatan bahwa pendekatan materi untuk siswa harus dibangun jauh sebelum pelaksanaan. Pemilihan siswa juga berpengaruh terhadap keefektifan pelaksanaan kegiatan. Lebih lanjut, kegiatan pelatihan soal-soal olimpiade memang diperlukan khususnya siswa di daerah Tarumajaya ini untuk lebih meningkatkan kualitas siswa di sana. Untuk penyelenggaraan PkM selanjutnya, pemilihan peserta kegiatan menjadi hal yang penting agar pelaksanaan kegiatan menjadi lebih fokus. Substansi materi kegiatan juga perlu dipilih sesuai kebutuhan khususnya daerah yang nanti menjadi lokasi kegiatan pengabdian. Pelatihan yang terkait dengan soal olimpiade juga sebaiknya tidak hanya diberikan kepada siswa, namun juga guru diberikan pembimbingan khusus untuk menyelesaikan soal-soal olimpiade.

\section{DAFTAR PUSTAKA}

Badan Pengembangan Sumber Daya Manusia Pendidikan dan Kebudayaan dan Penjaminan Mutu Pendidikan, Materi Pelatihan Guru Implementasi Kurikulum, Kementerian Pendidikan dan Kebudayaan Jakarta, 2013

Komariah, Kokom., Penerapan Pembelajara Problem Solving Model Polya Untuk Meningkatkan Kemampuan Pemecahan Masalah, Seminar Nasional. Yogyakarta: Universitas Negeri Yogyakarta, 
2011

Mulyasa, Praktik Penelitian Tindakan Kelas, Bandung: PT. Remaja Rosdakarya, 2009

Suharsimi Arikunto, dkk, Penelitian Tindakan Kelas, Jakarta: Bumi Aksara, 2015

Suherman, Erman., Common Textbook: Strategi Pembelajaran Matematika Kontemporer. JICA: FMIPA UPI, 2003

Sukayati dan Agus Suharjana, Pemanfaatan Alat Peraga Matematika Dalam Pembelajaran di SD, P4TK Matematika, Yogyakarata, 2009
Sutanto, A., Teori Belajar dan Pembelajaran di Sekolah Dasar, Jakarta: Prenada Media Grup, 2013.

Suyadi, Buku Panduan Guru Profesional: Penelitian Tindakan Kelas (PTK) Dan Penelitian Tindakan Sekolah (PTS), Andi Publisher.

van de Walle. J. (2007) Matematika Sekolah Dasar dan Menengah: Pengembangan Pengajaran. Alih Bahasa Suyono. Jakarta: Erlangga. Wardani, I. G. A. K, dkk, Penelitian Tindakan Kelas. Modul. Jakarta: Universitas Terbuka, 2006 